\title{
Correction: Use of Health Apps by Nurses for Professional Purposes: Web-Based Survey Study
}

Miguel Angel Mayer ${ }^{1 *}, \mathrm{MPH}, \mathrm{PhD}, \mathrm{MD}$; Octavi Rodríguez Blanco ${ }^{2 *}, \mathrm{RNC}, \mathrm{MSci}$; Antonio Torrejon ${ }^{2 *}$, RNC, BSciS, MSci

${ }^{1}$ Research Programme on Biomedical Informatics. Hospital del Mar Medical Research Institute, Universitat Pompeu Fabra, Barcelona, Spain

${ }^{2}$ Col-legi Oficial d'Infermeres i Infermers de Barcelona, Barcelona, Spain

*all authors contributed equally

\section{Corresponding Author:}

Antonio Torrejon, RNC, BSciS, MSci

Col-legi Oficial d'Infermeres i Infermers de Barcelona

Pujades 350

Barcelona, 08019

Spain

Phone: 34932128108

Email: atorrejon@coib.cat

\section{Related Article:}

Correction of: https://mhealth.jmir.org/2019/11/e15195

(JMIR Mhealth Uhealth 2020;8(4):e18516) doi: 10.2196/18516

In the manuscript "Use of Health Apps by Nurses for Professional Purposes: Web-Based Survey Study" (JMIR Mhealth Uhealth 2019;7(11):e15195) there was an error in the original published PDF. The original published PDF version of the manuscript available on the JMIR mHealth and uHealth website displayed the title as "Use of Health Apps by Nurses for Professional Purposes in Catalonia, Spain: Web-Based
Survey Study". The correct title is "Use of Health Apps by Nurses for Professional Purposes: Web-Based Survey Study". The PDF has now been revised to remove "in Catalonia, Spain". This correction notice will appear on the JMIR mHealth and uHealth website on April 30, 2020. Because the XML had been correctly submitted to all other repositories, it will not need to be resubmitted.

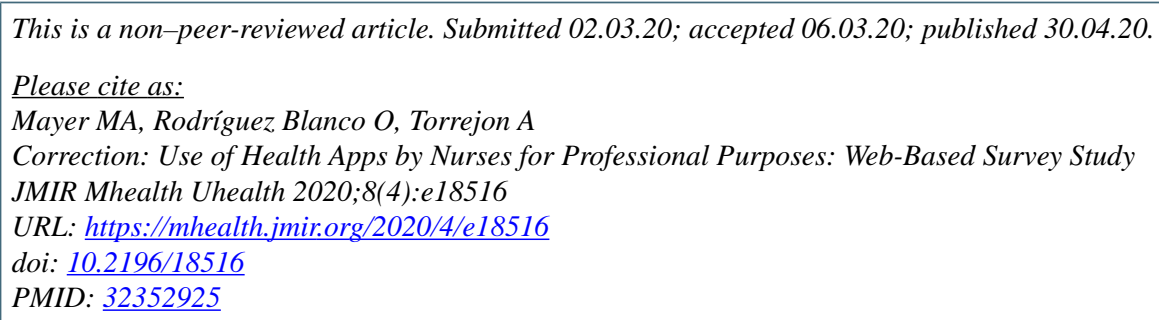

CMiguel Angel Mayer, Octavi Rodríguez Blanco, Antonio Torrejon. Originally published in JMIR mHealth and uHealth (http://mhealth.jmir.org), 30.04.2020. This is an open-access article distributed under the terms of the Creative Commons Attribution License (https://creativecommons.org/licenses/by/4.0/), which permits unrestricted use, distribution, and reproduction in any medium, provided the original work, first published in JMIR mHealth and uHealth, is properly cited. The complete bibliographic information, a link to the original publication on http://mhealth.jmir.org/, as well as this copyright and license information must be included. 